\title{
Taxonomic Notes: Names for the Higher Taxa and Their Impact on the Code of Nomenclature of Bacteria $\dagger$
}

\author{
HANS G. TRÜPER* \\ Institut für Mikrobiologie und Biotechnologie, Rheinische Friedrich-Wilhelms-Universität Bonn, \\ D-53115 Bonn, Germany
}

\begin{abstract}
General Consideration 5, chapter 1, of the International Code of Nomenclature of Bacteria (1990 Revision) states: "This Code of Nomenclature of Bacteria applies to all bacteria. The nomenclature of certain other microbial groups is provided for by other Codes: fungi and algae by the Botanical Code, protozoa by the Zoological Code, and viruses by the Virological Code when it is approved (see Appendix 1)." The extent of jurisdiction depends, therefore, on the usage applied to names of the highest taxa.
\end{abstract}

In the recent past the term "bacteria" has undergone two changes of meaning. After it had become unequivocally clear that the blue-green algae are real bacteria $(3,7)$ and the name cyanobacteria came into use for this group of microbes, the terms "bacteria" and "procaryotes" became synonymous, comprising all living organisms with the typical procaryotic cellular organization. However, Woese et al. (9) have given the term "bacteria," in contrast to "procaryotes," a new and more narrow definition in the nomenclatural and taxonomic sense.

rRNA sequence data proved that there exist two groups of structural procaryotes whose distance apart in relatedness far outmeasures those distances between plants, fungi, and animals (8). Therefore, Woese et al. (9) proposed the new rank of "domain" for the highest taxon, above kingdom, and assigned all living organisms to three domains: the Eucarya (comprising all eucaryotes), the Bacteria (comprising the eubacteria, including cyanobacteria, mitochondria, and chloroplasts), and the Archaea (comprising all the groups of archaebacteria).

From the viewpoint of bacteriology this taxonomic revision had been necessary for some time, because most zoologists and botanists would certainly not be willing to give up their views that animals, plants, and fungi form separate kingdoms, although everyone agrees that these three groups are all eucaryotes.

The Eucarya, on the same experimental basis of rRNA relatedness, now appear to consist of many more kingdoms than just the animals, plants, and fungi and comprise the

\footnotetext{
* Mailing address: Institut für Mikrobiologie und Biotechnologie, Rheinische Friedrich-Wilhelms-Universität Bonn, Meckenheimer Allee 168, D-53115 Bonn, Germany. Phone: (49) 228732320 . Fax: (49) 228737576.

† This section permits the presentation, in a concise form, of proposals or problems that require the attention of the International Committee on Systematic Bacteriology (ICSB) for formal discussion and informs colleagues internationally so that they may react if they wish to do.so. It may also be used as a source of information or to transmit information on approaches, concepts, or arguments arising from outside the pages of the IJSB, which already allows Letters to the Editor concerning publications in that journal. Contributions can be addressed to the Editor or communicated through an officer of the ICSB (see the listing on the title page of every issue) or through the ASM Journals Division as for papers. The contributions should concern matters appropriate to the scientific interests of the ICSB. For example, proposals regarding amendments to the Bacteriological Code should, by statute, be published 3 to 6 months in advance of the ICSB meeting, which is part of the program at IUMS Congresses of Microbiology (Bacteriology Division).
}

different kingdoms of microbial eucaryotes (4-6) that formerly had been lumped together as protists or protocists.

The terms Archaea (for archaebacteria) and Bacteria (for eubacteria) are increasingly used in the microbiological literature. Thus the possibility arises that the Archaea may not be considered bacteria, and a separate code of nomenclature may be postulated for them on the basis of sentence 1 in general Consideration 5, chapter 1 , of the International Code of Nomenclature of Bacteria (1990 Revision) (1). It is therefore necessary that the International Committee on Systematic Bacteriology (ICSB) take action in changing sentence 1 of Consideration 5.

I herewith propose to the ICSB a change of that sentence to: "This Code of Nomenclature of Bacteria applies to all procaryotes, including Archaea and Bacteria." I also propose that a change in the name of the Code be considered for its next revision to accord with the decision taken.

The term domain was surely not the optimal choice for a taxon above kingdom. Domain is a term used in protein chemistry and molecular biology for functional areas of large molecules and could lead to confusion; also, its meaning as a legal term and its common use to describe part of an estate or a realm render it less useful.

The term "Empire" or "Imperium," which clearly means something more than a kingdom, would have been more appropriate for ranking Eucarya, Bacteria, and Archaea.

The term "Bacteria" was a rather confusing choice, because microbiologists appeared to have consented to and adopted the dichotomy, "eubacteria" versus "archaebacteria." There is no doubt that "archae(o)bacteria" will survive besides Archaea even if it is only to avoid the confusing derivative words archaeologist and archaeology (in parallel with bacteriologist and bacteriology). In addition, most of the Archaea carry names now that identify them as "bacteria," e.g., Halobacterium, Methanobrevibacter, and Methanobacterium, or names that have a classical bacteriological flavor in combinations like Halococcus, Methanospirillum, and Methanosarcina. The Archaea are more closely related to the Eucarya than are the Bacteria, but this modern understanding is not likely to change this common usage. This will hold despite the recent publication of Olsen et al. (2), which is unnecessarily polemic in its disregard of the fact that former generations of microbiologists always had a more limited array of concepts and methods at hand than do their successors (which holds for all sciences and technologies, and even humankind).

The term "procaryotes" will not disappear, because it characterizes a cellular structure common to Archaea and Bacteria and is a handy, well-defined, and useful term, and this despite 
the attitude expressed by Olsen et al. (almost hatefully) in calling the procaryote-eucaryote dichotomy a "phylogenetic crutch."

In order to avoid confusion, which is the intent of Principle 1 of the Code, I herewith propose the term Eubacteria for those organisms we used to call eubacteria before Woese et al. (9) introduced the term "Bacteria" for them. This would be wise because it seems likely that more novel lineages will be discovered that parted from the main evolutionary stem after Eubacteria and before Archaea. Furthermore, I propose that the term Imperium (English: empire) be used for the highest taxon of living beings instead of the term domain.

As a consequence, Eucarya, Archaea, and Eubacteria should be the three Imperia. As a second consequence, the most deeply branching phyla in the Eubacteria will have to be considered kingdoms (Latin: Regnum, plural Regna), like the Euryarchaeota and Crenarchaeota within the Archaea (9). At present only two of the eubacterial kingdoms-so far proposed as classes-bear an appropriate name: the Firmicutes and the Proteobacteria.

I do not doubt that further eubacterial kingdom designations will follow in due time.

\section{REFERENCES}

1. Lapage, S. P., P. H. A. Sneath, E. F. Lessel, V. D. B. Skerman, H. P. R. Seeliger, and W. A. Clarke. 1992. International code of nomenclature of bacteria (1990 revision). Editor for the 1992 edition, P. H. A. Sneath. American Society for Microbiology, Washington, D.C.

2. Olsen, G. J., C. R. Woese, and R. Overbeek. 1994. The winds of (evolutionary) change: breathing new life into microbiology. J. Bacteriol. 176:1-6.

3. Rippka, R., J. Deruelles, J. B. Waterbury, M. Herdman, and R. Y. Stanier. 1979. Generic assignments, strain histories and properties of pure cultures of cyanobacteria. J. Gen. Microbiol. 111:1-61.

4. Sogin, M. L. 1991. The phylogenetic significance of sequence diversity and length variation in eukaryotic small subunit ribosomal RNA coding regions, p. 175-188. In J. G. Warren (ed.), New perspectives on evolution. Wiley-Liss, New York.

5. Sogin, M. L., H. J. Elwood, and J. H. Gunderson. 1986. Evolutionary diversity of the eukaryotic small subunit rRNA genes. Proc. Natl. Acad. Sci. USA 83:1383-1388.

6. Sogin, M. L., J. L. Gunderson, H. J. Elwood, R. A. Alonso, and D. A. Peatty. 1989. Phylogenetic meaning of the kingdom concept: an unusual ribosomal RNA from Giardia lamblia. Science 243:75-77.

7. Stanier, R. Y., W. R. Sistrom, T. A. Hansen, B. A. Whitton, R. W. Castenholz, N. Pfennig, V. N. Gorlenki, E. N. Kondratieva, K. E. Eimhjellen, R. Whittenbury, R. L. Gherna, and H. G. Trüper. 1978. Proposal to place the nomenclature of the cyanobacteria (bluegreen algae) under the rules of the International Code of Nomenclature of Bacteria. Int. J. Syst. Bacteriol. 28:335-336.

8. Woese, C. R. 1987. Bacterial evolution. Microbiol. Rev. 51:221-271.

9. Woese, C. R., O. Kandler, and M. L. Wheelis. 1990. Towards a natural system of organisms. Proposal for the domains Archaea and Bacteria. Proc. Natl. Acad. Sci. USA 87:4576-4579. 